\title{
GSSG-mediated Complex I defect in isolated cardiac mitochondria
}

\author{
CHIARA PASSARELLI $^{1 *}$, GIULIA TOZZI $^{1 *}$, ANNA PASTORE $^{2}$, ENRICO BERTINI $^{1}$ and FIORELLA PIEMONTE ${ }^{1}$ \\ ${ }^{1}$ Molecular Medicine Unit; ${ }^{2}$ Laboratory of Biochemistry, Children's Hospital \\ and Research Institute 'Bambino Gesù', Rome, Italy
}

Received December 14, 2009; Accepted February 3, 2010

DOI: 10.3892/ijmm_00000439

\begin{abstract}
The mitochondrial respiratory chain represents the major source of reactive oxygen species (ROS) in cells and its dysfunction may contribute to the pathogenesis of several diseases. In mitochondria, glutathione is the major redox buffer and is a good indicator for the redox environment of the cell. Indeed, overproduction of ROS decreases the ratio between reduced and oxidized glutathione leading the latter to bind to proteins by a mechanism called glutathionylation. In this study, we demonstrate that in isolated cardiac mitochondria the respiratory chain enzyme Complex I is highly susceptible to glutathionylation under conditions of oxidative stress, showing a significant dose- and time-dependent decrease of the activity after treatment with oxidized glutathione. Among respiratory chain enzymes, Complex I appears the most affected by the oxidant-mediated inactivation in isolated mitochondria. Also, in cultured cardiomyocytes CI activity was strongly inhibited after in vivo treatment with hydrogen peroxide. Noteworthy, HPLC analysis showed a significant increase of protein glutathionylation in oxidatively stressed cells and this rise is in vivo reverted after incubation of cells with anti-oxidant $\mathrm{N}$-acetylcysteine. These findings take particular importance given that CI represents the entry point of electrons into oxidative phosphorylation and that the threshold at which CI dysfunction affects ATP production is lower than that of any other OXPHOS complexes, making the enzyme particularly critical for the health of cells.
\end{abstract}

\section{Introduction}

The mitochondrial respiratory chain represents the major source of ROS in cells under both normal and pathophysiologic conditions (1). This ROS production contributes to mitochondrial damage in a range of pathologies and it is also

Correspondence to: Dr Fiorella Piemonte, Molecular Medicine Unit, Children's Hospital and Research Institute 'Bambino Gesù', P.za S. Onofrio, 4, I-00165 Rome, Italy

E-mail: piemonte@opbg.net

${ }^{*}$ Contributed equally

Key words: glutathione, oxidative stress, Complex I, mitochondria important in redox signalling from the organelle to the rest of the cell (2).

The reduced glutathione (GSH) and its oxidized form (GSSG) represent the major cellular redox buffer, therefore the ratio GSH/GSSG is a good indicator for the redox environment of the cell. Indeed, a decrease in this ratio is indicative of an increase in oxidative stress (3-5).

In mitochondria, overproduction of ROS decreases the ratio GSH/GSSG and this imbalance leads GSSG to bind to proteins by a mechanism called glutathionylation. Glutathionylation was shown to regulate, either positively or negatively, a variety of regulatory, structural, and metabolic proteins deeply influencing some important biological processes, including proliferation, apoptosis, differentiation and senescence $(5,6)$.

The proteins of the mitochondrial electron transport chain (ETC) are rich in thiol residues and Complex I is the major component of the ETC to host protein thiols $(7,8)$ besides being the main site of $\mathrm{O}_{2}^{-}$production in the mitochondrial respiratory chain $(9,10)$. Therefore, glutathionylation of some enzymes that are part of the respiratory chain may represent an important response to mitochondrial oxidative stress.

The aim of this study was to analyse the effect of glutathionylation on isolated cardiac mitochondria, in order to identify the redox-sensitive targets potentially involved in the regulation of mitochondrial function. Mitochondria were isolated from rat heart and treated with increasing concentrations of GSSG. The level of electron transport chain activities was monitored as a function of GSSG concentration and time of exposure.

\section{Materials and methods}

Mitochondria isolation. Rat hearts $(500 \mathrm{mg})$ were thawed in isolation buffer ( $210 \mathrm{mM}$ mannitol, $70 \mathrm{mM}$ saccharose, $50 \mathrm{mM}$ Tris, $10 \mathrm{mM}$ EDTA, and 0.5\% BSA; pH 7.4), cut in small pieces, digested for 15 min with trypsin, under agitation, and washed 2 times with isolation buffer supplemented with protease inhibitors (Complete, Roche Diagnostics, Penzberg, Germany). Tissue was then centrifuged at $4^{\circ} \mathrm{C}$ for $2 \mathrm{~min}$ at $100 \mathrm{x}$ g. Tissue was homogenized with a conical glass grinder in $1 \mathrm{ml}$ isolation buffer and the homogenate centrifuged at $4^{\circ} \mathrm{C}$ for $10 \mathrm{~min}$ at $820 \mathrm{x} \mathrm{g}$. The supernatant was collected and centrifuged at $4^{\circ} \mathrm{C}$ for $20 \mathrm{~min}$ at $6,800 \mathrm{x} \mathrm{g}$. The pellet obtained was resuspended in $1 \mathrm{ml}$ suspension buffer $(225 \mathrm{mM}$ 
mannitol, $75 \mathrm{mM}$ saccharose, $10 \mathrm{mM}$ Tris, and $0.1 \mathrm{mM}$ EDTA; $\mathrm{pH}$ 7.4) and centrifuged at $4^{\circ} \mathrm{C}$ for $10 \mathrm{~min}$ at $820 \mathrm{x} \mathrm{g}$. The mitochondria were then pelleted by centrifuging the supernatant for $20 \mathrm{~min}$ at $6,800 \mathrm{x} \mathrm{g}$ and immediately used for enzyme activity assays.

Cell lines and treatments. H9c2 cell line, derived from embryonic rat heart (11), was purchased from American Type Culture Collection (ATCC, Virginia, USA). Cells were cultured in high-glucose Dulbecco's modified Eagle's medium (DMEM) supplemented with $1.5 \mathrm{~g} / 1$ sodium bicarbonate, $1 \mathrm{mM}$ sodium pyruvate, $10 \%(\mathrm{v} / \mathrm{v})$ fetal bovine serum, $10 \%(\mathrm{v} / \mathrm{v})$ L-glutamine, $1 \%(\mathrm{v} / \mathrm{v})$ penicillin/streptomycin, at $37^{\circ} \mathrm{C}$ in a humidified atmosphere of $5 \% \mathrm{CO}_{2}$. Cells were fed every 23 days and sub-cultured once they reached $70-80 \%$ confluence, according to ATCC Product information sheet. Cells, at 80-90\% of confluence, were plated at an appropriate density (1:3) to begin experiments. Stock of cells were routinely frozen and stored in liquid $\mathrm{N}_{2}$. Cells were incubated with $100 \mu \mathrm{M} \mathrm{H}_{2} \mathrm{O}_{2}$, $10 \mathrm{nM}$ rotenone and $1 \mathrm{mM} \mathrm{N}$-acetylcysteine (NAC) for $30 \mathrm{~min}$, $1 \mathrm{~h}$ and $1 \mathrm{~h}$, respectively. Blank cells (not treated) received an equivalent amount of DMSO (the final concentration of DMSO does not exceed $0.1 \%$ ). After treatment, cells were harvested and collected to perform experiments.

Measurement of reduced (RED GSH) and protein-bound (GS-Pro) glutathione. Mitochondria and H9c2 cells, differently treated, were sonicated three times for $2 \mathrm{sec}$ in $0.1 \mathrm{ml}$ of $0.1 \mathrm{M}$ potassium-phosphate buffer, $\mathrm{pH}$ 7.2. After sonication, $50 \mu \mathrm{l}$ of $12 \%$ sulfosalicylic acid were added, and GSH content on the acid-soluble fraction was determined (Red GSH). The protein pellet was dissolved in $150 \mu 1$ of $0.1 \mathrm{~N} \mathrm{NaOH}$, and protein bound glutathione (GS-Pro) determined. The derivatization and chromatography procedures were performed, with little modifications, as previously reported (12).

Determination of mitochondrial enzyme activities. Heart mitochondrial preparations were stored on ice and used within $3 \mathrm{~h}$ of preparation. The mitochondria and $\mathrm{H} 9 \mathrm{c} 2$ cells were resuspended in $50 \mu \mathrm{l}$ of suspension buffer and $10 \mathrm{mM}$ phosphate buffer, $\mathrm{pH} 7.4$, respectively. All enzyme activities were measured spectrophotometrically with a $\lambda 25$ (Perkin Elmer, Waltham, MA, USA). NADH-CoQ oxidoreductase (Complex I) activity was assayed in assay buffer containing $20 \mathrm{mM}$ phosphate buffer, $0.2 \mathrm{mM} \mathrm{NADH}, 1 \mathrm{mM} \mathrm{NaN}_{3}, 0.1 \%$ BSA, $1 \mathrm{mM}$ EDTA $\mathrm{Na}_{4}, 100 \mu \mathrm{g}$ proteins by following the rotenone-sensitive initial rate of NADH oxidation at $340 \mathrm{~nm}$ $\left(\Delta \varepsilon=6.81 \mathrm{mM}^{-1} \mathrm{~cm}^{-1}\right)$. Rotenone $(5 \mu \mathrm{M})$ inhibited the enzymatic activity by $70-80 \%$. Reaction started with addition of $50 \mu \mathrm{M}$ $\mathrm{CoQ}_{1}$.

Succinate-Co Q oxidoreductase (Complex II) was determined by following the reduction of 2,6-dichlorophenol indophenol (DCPIP) coupled with reduction of decylubiquinone (DB). The assay buffer contains $50 \mathrm{mM}$ phosphate buffer (pH 7.0), $1.5 \mathrm{mM} \mathrm{NaCN}, 0.1 \mathrm{mM}$ DCPIP and $80 \mu \mathrm{g}$ proteins. After $5 \mathrm{~min}$ of incubation, reaction starts with $16 \mathrm{mM}$ succinate and $50 \mu \mathrm{M} \mathrm{DB}$, and it is followed at $600 \mathrm{~nm}$ $\left(\Delta \varepsilon=19.1 \mathrm{mM}^{-1} \mathrm{~cm}^{-1}\right)$.

CoQ-cytocrome c oxidoreductase (Complex III) was assayed in a buffer containing $50 \mathrm{mM}$ phosphate buffer
Table I. Effect of GSSG on mitochondrial electron transport complex activities.

\begin{tabular}{lcc}
\hline Enzyme & -GSSG & $+1 \mathrm{mM} \mathrm{GSSG}$ \\
\hline Complex I & $733 \pm 6$ & $492 \pm 46$ \\
Complex II & $314 \pm 7$ & $308 \pm 23$ \\
Complex III & $382 \pm 9$ & $340 \pm 7$ \\
Complex IV & $5,509 \pm 25$ & $5,234 \pm 428$ \\
\hline
\end{tabular}

Mitochondria were incubated in the absence and presence of $1 \mathrm{mM}$ GSSG for $10 \mathrm{~min}$ at $37^{\circ} \mathrm{C}$ and enzyme activities determined as described under Materials and methods. Values are expressed as $\mathrm{nmol} / \mathrm{min} / \mathrm{mg}$ of mitochondrial protein and represent the means $(\mathrm{n}=3) \pm \mathrm{SD}$.

(pH 7.0), $2 \mathrm{mM} \mathrm{NaN}, 0.1 \%$ BSA, $50 \mu \mathrm{M}$ cytocrome c and $80 \mu \mathrm{g}$ proteins. Reaction starts with addition of $50 \mu \mathrm{M} \mathrm{DBH}_{2}$ and the reduction of cytocrome $\mathrm{c}$ was followed at $550 \mathrm{~nm}$ $\left(\Delta \varepsilon=18.5 \mathrm{mM}^{-1} \mathrm{~cm}^{-1}\right)$.

Cytochrome c oxidase (Complex IV) activity was measured by following the oxidation of cytochrome $\mathrm{c}$ at $550 \mathrm{~nm}$ $\left(\Delta \varepsilon=18.5 \mathrm{mM}^{-1} \mathrm{~cm}^{-1}\right)$. Enzymatic activity was estimated in $10 \mathrm{mM}$ phosphate buffer (pH 7.0) containing $0.025 \%$ laurylmaltoside, $80 \mu \mathrm{g}$ proteins, $1 \mathrm{mg} / \mathrm{ml}$ reduced cytochrome $\mathrm{c}$.

Citrate synthase activity was used as mitochondrial matrix enzymatic marker. Mitochondrial proteins ( $80 \mu \mathrm{g}), 0.25 \mathrm{mM}$ acetyl-coenzyme A, and $0.2 \mathrm{mM}$ DTNB were added to a Tris- $\mathrm{HCl}$ buffer $(10 \mathrm{mM}), \mathrm{pH} 7.4$, containing $0.2 \%(\mathrm{v} / \mathrm{v})$ Triton X-100. The reaction was started by the addition of $0.4 \mathrm{mM}$ oxalacetate and the initial rate was measured following the reduction of DTNB at $412 \mathrm{~nm}\left(\Delta \varepsilon=13.6 \mathrm{mM}^{-1} \mathrm{~cm}^{-1}\right)$. Protein concentrations were quantified by BCA-protein assay (Sigma-Aldrich, St. Louis, MI, USA).

Analysis of glutathione-conjugates by Western blotting. Isolated mitochondria (20 $\mu \mathrm{g})$ were applied onto $12 \%$ SDSpolyacrylamide gel electrophoresis and proteins were transferred onto a nitrocellulose membrane overnight at $70 \mathrm{~mA}$. Membrane was blocked with 5\% non fat dry milk in TBST (100 mM NaCl and $10 \mathrm{mM}$ Tris- $\mathrm{HCl}, \mathrm{pH} 7.8$ containing $0.1 \%$ Tween 20 ) for $2 \mathrm{~h}$, at room temperature, and probed with monoclonal anti-GSH antibody $(1 / 1,000)$ (Virogen, Watertown, MA, USA) and/or with monoclonal antiComplex I-51 kDa subunit antibody $(1 / 3,000)$ (Santa Cruz Biotechnology, CA, USA). Antibody incubation was followed by a horseradish peroxidase-conjugated goat anti-mouse and anti-rabbit secondary antibodies $(1: 25,000)$ (Amersham Bioscience, Buckinghamshire, UK). Immunoreactive proteins were visualized by enhanced chemiluminescence (Amersham Bioscience, Buckinghamshire, UK). Stripping of membrane was performed in a buffer containing $25 \mathrm{mM}$ glycine- $\mathrm{HCl}$, $\mathrm{pH} 2.1 \% \mathrm{SDS}$, for $30 \mathrm{~min}$, at room temperature.

Identification of glutathionylated CI by immunoprecipitation. Mitochondria $(60 \mu \mathrm{g})$, re-suspended in $150 \mu 1 \mathrm{H}_{2} \mathrm{O}$ and sonicated, were incubated with $10 \mu \mathrm{l}$ anti-GSH antibody $(10 \mu \mathrm{g})$ overnight at $4^{\circ} \mathrm{C}$ on a rocker platform. $20 \mu \mathrm{l}$ of resuspended volume of Protein G Plus-Agarose (Santa Cruz 
A

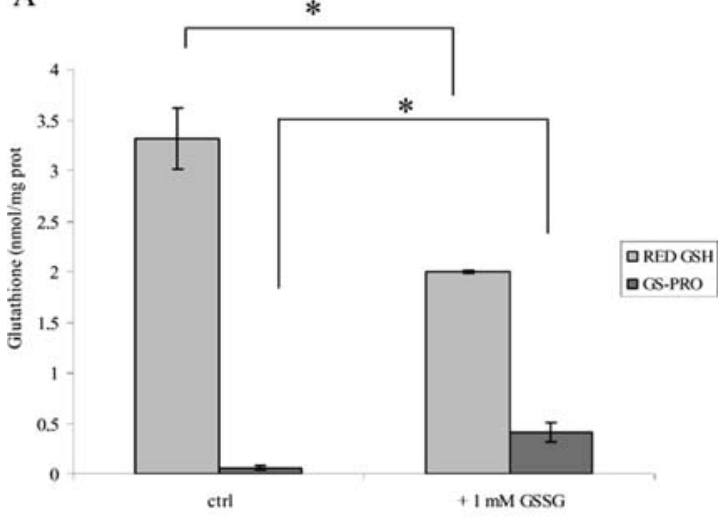

B

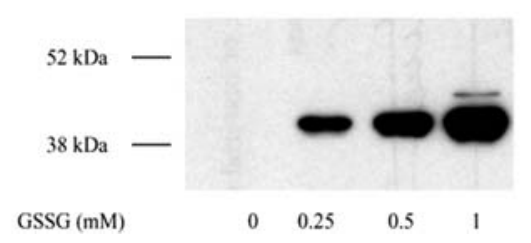

Figure 1. Effect of GSSG on protein glutathionylation of isolated cardiac mitochondria. (A) GSH bound to proteins (GS-Pro) of isolated cardiac mitochondria was determined by HPLC analysis after incubating $80 \mu \mathrm{g}$ mitochondria for $15 \mathrm{~min}$ at $37^{\circ} \mathrm{C}$ with $1 \mathrm{mM}$ GSSG. (B) Western blot analysis of $20 \mu \mathrm{g}$ mitochondria treated with increasing $(0-1 \mathrm{mM})$ amounts of GSSG for $15 \mathrm{~min}$ at $37^{\circ} \mathrm{C}$, showing protein glutathionylation determined by anti-GSPro antibody. All data are represented as the mean $\pm \mathrm{SD}$ of three experiments "p $<0.05$ vs. untreated mitochondria. For details, see Materials and methods.

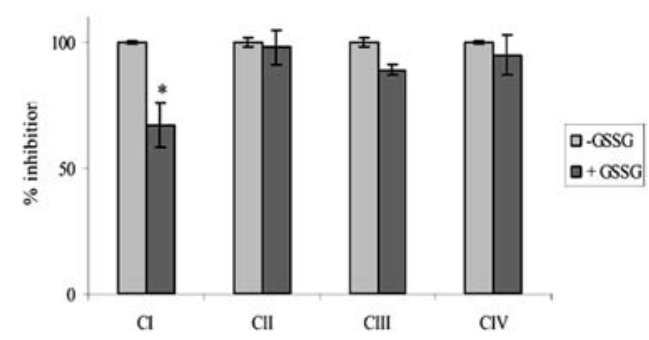

Figure 2. Effect of GSSG on the respiratory chain enzyme activities. Isolated cardiac mitochondria were incubated with $1 \mathrm{mM}$ GSSG for $15 \mathrm{~min}$ and the respiratory chain enzyme activities were spectrophotometrically assayed as reported in Materials and methods. Data are expressed as \% of inhibition of activity with respect to untreated mitochondria. ${ }^{*} \mathrm{p}<0.05$.

Biotechnology, CA, USA) were added to the solution and incubated at $4^{\circ} \mathrm{C}$ for $1 \mathrm{~h}$ on a rocker platform. The pellet was collected by spinning for $10 \mathrm{sec}$, at $4^{\circ} \mathrm{C}$ and washed 4 times with suspension buffer. After final wash, the pellet was resuspended in $20 \mu 1$ electrophoresis sample buffer, boiled for 4 min, loaded onto reducing 8\% SDS-polyacrylamide gel electrophoresis for Western blot analysis, and revealed with anti-Complex I-51 kDa subunit antibody $(1: 3,000)$.

\section{Results}

To induce protein glutathionylation, mitochondria were incubated with various amounts of GSSG (0-1 mM) at $37^{\circ} \mathrm{C}$ for $10 \mathrm{~min}$. As determined by HPLC analysis (Fig. 1A), total glutathionylated protein level was significantly enhanced, ranging from $0.06 \pm 0.1$ to $0.41 \pm 0.1$, (mean $\pm \mathrm{SD}$ ) $\mathrm{nmol} / \mathrm{mg}$ prot.
A

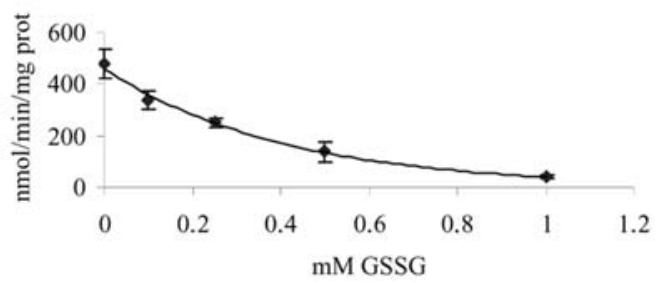

B

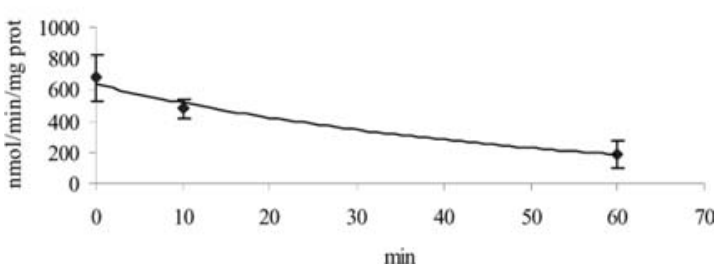

Figure 3. Dose and time-dependent GSSG inhibition of Complex I activity. (A) Isolated cardiac mitochondria $(100 \mu \mathrm{g})$ were incubated in presence of various concentrations $(0-1 \mathrm{mM})$ of GSSG for $15 \mathrm{~min}$ at $37^{\circ} \mathrm{C}$ and the enzyme activity determined as reported in Materials and methods. (B) CI activity was measured by incubating $100 \mu \mathrm{g}$ of isolated mitochondria with $1 \mathrm{mM}$ GSSG for a time ranging between $0-60 \mathrm{~min}$ at $37^{\circ} \mathrm{C}$. Data are reported as the mean $\pm \mathrm{SD}$ of three experiments and are expressed as $\mathrm{nmol} / \mathrm{min} / \mathrm{mg}$.

after incubation with $1 \mathrm{mM}$ GSSG. When reaction mixture was separated by SDS-PAGE and immunoblotted with the monoclonal antibody against glutathionylated proteins, GSSG treatment led to glutathionylation of a number of proteins whose MW ranged between $38-52 \mathrm{kDa}$ and the signal was enhanced proportionally to the GSSG dose (Fig. 1B). Glutathionylation might influence respiratory chain enzymes, thus we analyzed the enzymatic activity of all complexes on GSSG-treated isolated mitochondria (Table I). As shown in Fig. 2, CI suffers more than the other respiratory chain enzymes of the inactivation by glutathionylation and the GSSG inhibition was dose- (Fig. 3A) and time-dependent (Fig. 3B), with 30-60 min incubation leading to substantial inactivation of Complex I.

Thus, in light of the inactivating effect of GSSG, we tested the possibility that one of the glutathionylated proteins observed on the isolated cardiac mitochondria after oxidation was CI. Western blot analysis of mitochondria incubated with $1 \mathrm{mM}$ GSSG showed that the band recognized by the GS-Pro antibody (Fig. 4A) co-migrated with the band revealed with anti-Complex I-51 kDa subunit (Fig. 4B), after stripping the nitrocellulose and reprobing the membrane with an antiComplex I-51 kDa subunit. The involvement of protein glutathionylation is confirmed by the decrease of the immunoreactivity in presence of the reducing agent dithitreitol (DTT) (Fig. 4A), also suggesting the reversibility of the process. The identification of CI as a sensitive target of glutathionylation was then demonstrated by immunoprecipitating the GSSGtreated mitochondria by GS-Pro antibody and analyzing by Western blotting for the 51-kDa subunit of Complex I. As reported in Fig. 4C, CI was highly glutathionylated in oxidized cardiac mitochondria and, interestingly, it appears constitutively glutathionylated even under physiological conditions.

The susceptibility of $\mathrm{CI}$ to the inactivation following oxidation has also been confirmed in vivo on cultured cardio- 
A

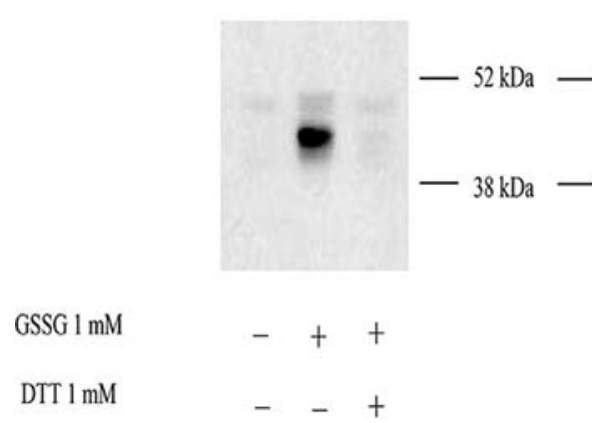

B

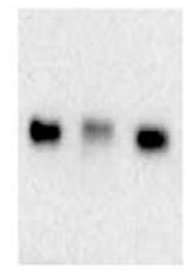

$-++$

$-\quad+$
$\mathrm{C}$

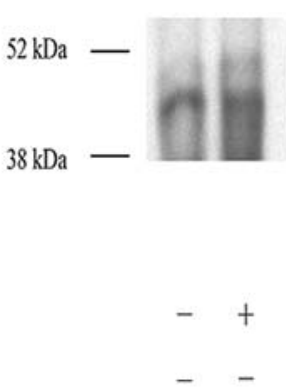

Figure 4. Identification of glutathionylated CI in isolated cardiac mitochondria. (A) Mitochondrial proteins $(20 \mu \mathrm{g})$, incubated with and without $1 \mathrm{mM}$ GSSG for $15 \mathrm{~min}$ at $37^{\circ} \mathrm{C}$, were separated by not-reducing SDS-PAGE and transferred to nitrocellulose. The glutathione conjugates were probed with a monoclonal antiGSPro antibody $(1 / 1,000)$. (B) Nitrocellulose was stripped and re-probed with anti-CI $(51 \mathrm{kDa}$ subunit) antibody $(1 / 3,000)$. (C) Mitochondria (60 $\mu \mathrm{g})$, incubated with and without $1 \mathrm{mM} \mathrm{GSSG}$ for $15 \mathrm{~min}$ at $37^{\circ} \mathrm{C}$, were immunoprecipitated with anti-GSPro antibody and revealed with anti-CI (51 kDa subunit) antibody. The blots are representative of one of three independent experiments. For details, see Materials and methods.

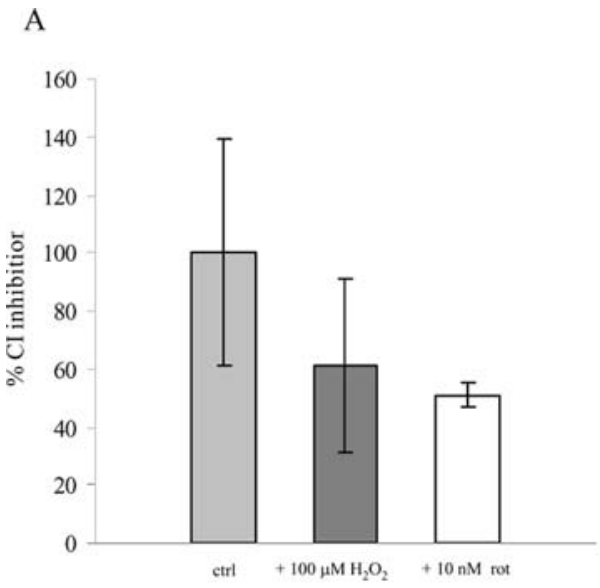

B

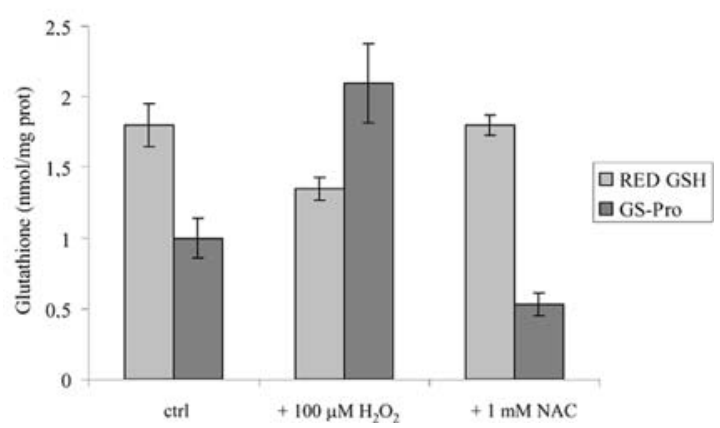

Figure 5. Effect of pro and anti-oxidant agents on $\mathrm{H} 9 \mathrm{c} 2$ cardiomyocytes. (A) Cell lysates $(150 \mu \mathrm{g})$, in vivo treated with $100 \mu \mathrm{M} \mathrm{H}_{2} \mathrm{O}_{2}$ and $10 \mathrm{nM}$ rotenone for $30 \mathrm{~min}$ and $1 \mathrm{~h}$ respectively, were spectrophotometrically assayed for $\mathrm{Cl}$ activity. Data are expressed as \% inhibition of activity with respect to the untreated cardiomyocytes. (B) GSH bound to the proteins (GS-Pro) was determined by HPLC analysis on $100 \mu \mathrm{g}$ cell lysates after in vivo treatment with $100 \mu \mathrm{M} \mathrm{H}_{2} \mathrm{O}_{2}$ and $1 \mathrm{mM} \mathrm{NAC}$, for $30 \mathrm{~min}$ and $1 \mathrm{~h}$ respectively. Data are reported as the mean $\pm \mathrm{SD}$ of three experiments and are expressed as nmol/mg.

myocytes, where CI activity was strongly (40\%) inhibited after incubation for 30 min with $\mathrm{H}_{2} \mathrm{O}_{2}$ (Fig. 5). A comparable inactivation was obtained when cells were in vivo treated with rotenone, a specific inhibitor of $\mathrm{CI}$ (Fig. 5A). The in vivo treatment of cardiomyocytes with $\mathrm{H}_{2} \mathrm{O}_{2}$ caused a significant increase of protein glutathionylation, as measured by HPLC analysis (Fig. 5B). Noteworthy, protein glutathionylation is in vivo reverted after incubation of cells with the anti-oxidant $\mathrm{N}$-acetylcysteine (NAC).

\section{Discussion}

Impairment of Complex I activity has been described in several neurodegenerative diseases including Parkinson's, hereditary spastic paraplegia and Huntington's disease $(13,14)$. Oxidation of cysteine residues in Complex I may play a role in its inhibition. Indeed, Complex I is a regulable and vulnerable pacemaker in mitochondrial respiratory function (15) and several studies have provided evidence of phosphorylation of subunits of Complex I effecting on electron transfer and in superoxide production.

$\mathrm{CI}$ is a membrane bound multimeric enzyme comprising at least 45 subunits and catalysing NADH oxidation and ubiquinone reduction coupled to proton pumping across the inner membrane (16-19). It contains reactive thiols on the 75and 51-kDa subunits that interacting with the mitochondrial glutathione pool may be implicated in oxidative damage in many pathologies $(7,8,20,21)$.

In mitochondria, GSH is converted to GSSG under conditions of oxidative stress and previous studies have reported the in vitro glutathionylation of the purified Complex I after exposure to glutathione disulfide (GSSG) $(7,22)$.

In our study, we showed that $\mathrm{CI}$ is the respiratory chain enzyme mostly affected by GSSG-induced oxidative stress in isolated cardiac mitochondria. Its enzyme activity results significantly decreased after oxidation and this finding takes particular importance given that CI represents the entry point of electrons into oxidative phosphorylation and that the threshold at which CI dysfunction affects ATP production is lower than that of any other OXPHOS complexes $(\sim 25 \%$ reduction in Complex I activity is sufficient to reduce $\mathrm{O}_{2}$ consumption and ATP synthesis) (23).

However, despite its critical role in ETC, CI is the major source of ROS in mitochondria and its inhibition may induce collateral damage to cells, thereby amplifying the initial dysfunction of the Complex itself. In this context, gluta- 
thionylation may become a key molecular event in redox regulation of mitochondrial functions (24-28). Indeed, the redox pool in mitochondria is rich of glutathione, with a physiological concentration of 5-10 mM (29). An overproduction of ROS leads to an imbalance of the GSH/GSSG ratio sensitising the mitochondrial proteins to glutathionylation. By this mechanism, mitochondria could regulate redox signaling in response to the changes of glutathione pool occurring during oxidative stress and CI plays a role as a target sensitive to ROS fluctuations.

\section{References}

1. Murphy MP: How mitochondria produce reactive oxygen species. Biochem J 417: 1-13, 2009.

2. Droge W: Free radicals in the physiological control of cell function. Physiol Rev 82: 47-95, 2002.

3. Jones DP, Go YM, Anderson CL, Ziegler TR, Kinkade JM Jr and Kirlin WG: Cysteine/cystine couple is a newly recognized mode in the circuitry for biologic redox signaling and control. FASEB J 18: 1246-1248, 2004.

4. Ghezzi P: Regulation of protein function by glutathionylation. Free Rad Res 39: 573-580, 2005.

5. Dalle-Donne I, Milzani A, Gagliano N, Colombo R, Giustarini D and Rossi R: Molecular mechanisms and potential clinical significance of S-glutathionylation. Antioxid Redox Signal 10: 445-473, 2008

6. Circu ML and Aw TY: Glutathione and apotosis. Free Rad Res 42: 689-760, 2008

7. Beer SM, Taylor ER, Brown SE, Dahm CC, Costa NJ, Runswick MJ and Murphy MP: Glutaredoxin 2 catalyzes the reversible oxidation and glutathionylation of mitochondrial membrane thiol proteins: implications for mitochondrial redox regulation and antioxidant defense. J Biol Chem 279: 47939-47951, 2004.

8. Taylor ER, Hurrell F, Shannon RJ, Lin TK, Hirst J and Murphy MP: Reversible glutathionylation of Complex I increases mitochondrial superoxide formation. The J Biol Chem 278: 19603-19610, 2003.

9. Han D, Williams E and Cadenas E: Mitochondrial respiratory chain-dependent generation of superoxide anion and its release into the intermembrane space. Biochem J 353: 411-416, 2001.

10. Lambert AJ and Brand MD: Inhibitors of the quinone-binding site allow rapid superoxide production from mitochondrial NADH: ubiquinone oxidoreductase (complex I). J Biol Chem 279: 39414-39420, 2004

11. Kimes BW and Brandt BL: Properties of a clonal muscle cell line from rat heart. Exp Cell Res 98: 367-381, 1976.

12. Pastore A, Piemonte F, Locatelli M, Lo Russo A, Gaeta LM, Tozzi G and Federici G: Determination of blood total, reduced and oxidized glutathione in pediatric subjects. Clin Chem 47: 1467-1469, 2001.

13. Papa S, Petruzzella V, Scacco S, Sardanelli AM, Iuso A, Panelli D, Vitale R, Trentadue R, De Rasmo D, Capitanio N, Piccoli C, Papa F, Scivetti M, Bertini E, Rizza T and De Michele G: Pathogenetic mechanisms in hereditary dysfunctions of complex I of the respiratory chain in neurological diseases. Biochim Biophys Acta 1787: 502-517, 2009.
14. Orth M and Schapira AHV: Mitochondria and degenerative disorders. Am J Med Genet 106: 27-36, 2001.

15. Papa S, De Rasmo D, Scacco S, Signorile A, Technikova-Dobrova Z, Palmisano G, Sardanelli AM, Papa F, Panelli D, Scaringi R and Santeramo A: Mammalian Complex I: a regulable and vulnerable pacemaker in mitochondrial respiratory function. Biochim Biophys Acta 1777: 719-728, 2008.

16. Brandt U: Energy converting NADH: quinone oxidoreductase (complex I). Ann Rev Biochem 75: 69-92, 2006.

17. Hirst J, Carrol J, Fearnley IM, Shannon RJ and Walker JE: The nuclear encoded subunits of complex I from bovine heart mitochondria. Biochim Biophys Acta 1604: 135-150, 2003.

18. Sazanov LA: Respiratory complex I: mechanistic and structural insights provided by the crystal structure of the hydrophilic domain. Biochemistry 46: 2275-2288, 2007.

19. Carrol J, Fearnley IM, Skehell JM, Shannon RJ, Hirst J and Walker JE: Bovine complex I is a complex of 45 different subunits. J Biol Chem 281: 32724-32727, 2006.

20. Murphy RM, Dutka TL and Lamb GD: Hydroxyl radical and glutathione interactions alter calcium sensitivity and maximum force of the contractile apparatus in rat skeletal muscle fibres. J Physiol 586: 22003-22016, 2008.

21. Lin TK, Hughes G, Muratovska A, Blaikie FH, Brookes PS, Darley-Usmar V, Smith RA and Murphy MP: Specific modifications of mitochondrial protein thiols in response to oxidative stress: a proteomic approach. J Biol Chem 277: 17048-17056, 2002.

22. Hurd TR, Requejo R, Filipovska A, Brown S, Prime TA, Robinson AJ, Fearnley IM and Murphy MP: Complex I within oxidatively stressed bovine heart mitochondria is glutathionylated on Cys-531 and Cys-704 of the 75-kDa subunit. J Biol Chem 283: 24801-24815, 2008.

23. Davey GP, Peuchen S and Clark JB: Energy Thresholds in brain mitochondria: potential involvement in neurodegeneration. J Biol Chem 273: 12753-12757, 1998.

24. Cotgreave IA and Gerdes RG: Recent trends in glutathione biochemistry. Glutathione-protein interactions: a molecular link between oxidative stress and cell proliferation? Biochm Biophys Res Commun 242: 1-9, 1998.

25. Klatt P and Lamas S: Regulation of protein function by Sglutathionylation in response to oxidative and nitrosative stress. Eur J Biochem 267: 4928-4944, 2000.

26. Fratelli M, Demol H, Puype M, Casagrande S, Eberini L, Salmona M, Bonetto V, Mengozzi M, Duffieux F, Miclet E, Bachi A, Vandekerckhove J, Gianazza E and Ghezzi P: Identification by redox proteomics of glutathionylated proteins in oxidatively stressed human T lymphocytes. Proc Natl Acad Sci USA 99: 3505-3510, 2002.

27. Giustarini D, Rossi R, Milzani A, Colombo R and Dalle-Donne I: S-glutathionylation: from redox regulation of protein functions to human diseases. J Cell Mol Med 8: 201-212, 2004.

28. Dalle-Donne I, Rossi R, Giustarini D, Colombo R and Milzani A: S-glutathionylation in protein redox regulation. Free Radic Biol Med 43: 883-98, 2007.

29. Costa NJ, Dahm CC, Hurrell F, Taylor ER and Murphy MP: Interactions of mitochondrial thiols with nitric oxide. Antioxid Redox Signaling 5: 291-305, 2003. 